DOI: $10.17805 / z p u .2016 .4 .12$

\title{
Место Индии в евразийском мировоззрении Рерихов *
}

\author{
A. В. ИвАНОВ \\ (АЛТАЙСКИЙ ГОСУДАРСТВЕННЫЙ АГРАРНЫЙ УНИВЕРСИТЕТ), \\ И. В. ФОТИЕВА \\ (АЛТАЙСКИЙ ГОСУДАРСТВЕННЫЙ УНИВЕРСИТЕТ)
}

Рост интереса к евразийскому учению подтверждается целым рядом исследований как в России, так и за рубежом. В их русле заслуживает внимания дискуссия о том, каким странам в дополнение к выделенным основателями учения можно придать статус евразийских. Эта тема представляется перспективной не только в плане ее теоретической значимости, но и в связи с необходимостью осмысления возрастающей геополитической роли евразийского пространства.

Авторы разбирают тезис о том, что в трудах семьи Рерихов, в особенности созданных на основе материалов Трансгималайской экспедиции, было начато обоснование статуса Индии как евразийской страны. Утверждается, что само наследие семьи Рерихов может рассматриваться как относительно самостоятельная вариация евразийской идеи, преодолевающая многие недостатки классического евразийства и обладающая серьезным эвристическим и прогностическим потенциалом в нынешней исторической ситуации.

Во взглядах Рерихов была преодолена ограниченность взгляда евразийцев, которыми не были по-настоящему учтены Индия и ее органическое единство с Северной (Внутренней) Евразией, т. е. евразийским этнокультурным пространством в узком смысле. Это единство обусловливается, по мнению Рерихов, многочисленными свидетельствами кросскультурных связей между народами, населяющими данное пространство. В качестве фактических подтверждений отмечаются открытие распространенности от Тибета до Причерноморья скифско-сарматского звериного стиля; обнаружение в ходе экспедиции целого ряда отдельных артефактов, также говорящих в пользу данной гипотезы; обоснование масштабного культурно-духовного влияния буддизма в Центральной и Средней Азии в первой половине первого тысячелетия нашей эры; мировоззренческая близость культур Индии к общему евразийскому «духу», подтверждаемая сегодня различными исследованиями.

В заключении отмечается особое значение в многовекторном объединении Евразии Алтая как наиболее репрезентативного биосферного и этнокультурного региона и его связи с Гималайским горным регионом в Индии.

Ключевые слова: евразийство; Евразия; Индия; Рерихи; Н. К. Рерих; Ю. Н. Рерих; Трансгималайская экспедиция; институт «Урусвати»; кросс-культурные связи; Алтай

\section{BВЕАЕНИЕ}

$\mathrm{B}$ последние десятилетия, как известно, отмечается рост внимания к евразийскому учению. В данном направлении ведется ряд разнонаправленных исследований как в России, так и за рубежом. В частности, можно отметить работы О. Босса, Ч. Гальперина, М. Аарюэль, А. С. Панарина, С. С. Хоружего и ряд других. Исследования дополнились дискуссией о том, каким странам, в дополнение к выделенным основателями

* Работа выполнена при поддержке РГНФ и администрации Алтайского края (проект «Алтай и Гималаи как уникальные культурно-биосферные регионы Евразии: поиск общих ценностей, эколого-экономических стратегий, социокультурных параллелей», грант № 16-13-22002).

The research was supported by the Russian Foundation for the Humanities and the administration of the Altai Region (project «The Altai and Himalayas as unique cultural-biospheric areas of Eurasia: the search of the common values, environmental-economic strategies and social-cultural parallels», grant No. 16-13-22002). 
учения, в той или иной мере можно придать статус «евразийских». Эта тема представляется перспективной не только в плане ее теоретической значимости, но и в связи с необходимостью осмысления возрастающей геополитической роли евразийского пространства, так как идущие здесь процессы играют первостепенную роль в ситуации нестабильности современного мира

В своих предыдущих работах мы, а также наши коллеги уже обращали внимание на страну, которая с большим основанием может претендовать на евразийский статус, на Индию (Иванов, 2003; Иванов, Попков, Тюгашев, Шишин, 2007; Иванов, Фотиева, Шишин, 2001). Развивая данный подход, в предлагаемой статье постараемся очертить вклад, внесенный в обоснование этого тезиса Н. К. Рерихом и членами его семьи как выдающимися исследователями Индии в целом ряде сфер (культуры, этнографии, истории и др.). Можно отметить, что осмысление еще далеко не изученного, хранящегося в архивах наследия Рерихов сегодня приобретает особое значение в связи не только с его научной ценностью, но и с отчетливой гуманистической направленностью, что особенно важно в условиях формирования многополярного мира и поиска ориентиров, способных противостоять растущему хаосу и консолидировать мировое сообщество. При этом весьма показательной является существенная близость многих идей Рерихов к ключевым идеям евразийства, что, на наш взгляд, демонстрирует наличие общего евразийского мировоззренческого и цивилизационного вектора, все более утверждающего себя в качестве альтернативы пока еще доминирующему западно-ориентированному техногенно-потребительскому цивилизационному подходу.

\section{РЕРИХИ И ЕВРАЗИЙСКОЕ УЧЕНИЕ}

В литературе до сих пор дискуссионным остается вопрос, можно ли считать наследие Рерихов разновидностью евразийского течения. Этому посвящен целый ряд исследований (см.: Зелинский, 1992; Ключников: Электронный ресурс и др.), в том числе и одного из авторов данной статьи (Иванов, 2003). На наш взгляд, в целом на данный вопрос следует ответить утвердительно.

Прежде всего, отметим, что Рерихи были не только хорошо знакомы со взглядами евразийцев, но и поддерживали с ними контакты. Так, Ю. Н. Рерих вплоть до последних дней жизни состоял в научной переписке с крупнейшим историком евразийской ориентации Г. В. Вернадским, а после возвращения в СССР профессиональные и дружеские отношения сложились у него с $\Lambda$. Н. Гумилевым. Ученик Ю. Н. Рериха А. Н. Зелинский вспоминает: посетив Спасо-Преображенский монастырь в Переяславле-Залесском, Ю. Н. Рерих промолвил, имея в виду князя Александра Невского: «Вот здесь крестили первого евразийца» (Зелинский, 2003: 57). При этом вся семья Рерихов разделяла и ряд ключевых евразийских идей. Это касается и критики европоцентризма, и представления о России как о срединном культурно-географическом мире (или цивилизации), впитавшей в себя культурные достижения Востока и Запада, но приобретшей в ходе исторического развития самобытные черты, и признания важнейшей роли кочевого мира в контактах между оседлыми цивилизациями, и необходимости усиления восточного вектора российской внешней политики.

Вместе с тем взгляды семьи Рерихов вызревали во многом параллельно движению евразийцев и преодолевали многие присущие им недоговоренности и заблуждения. Это касается прежде всего гипертрофированного этатизма евразийцев (в первую очередь у $\Lambda$. П. Карсавина, которого, правда, лишь отчасти можно отнести к данному течению), т. е. переоценки ими государственно-централизованных начал в жизни того 
или иного народа, и, наоборот, явной недооценки общинно-вечевых и кооперативных начал в жизни России - Евразии. Аругим слабым әлементом в мировоззрении классиков евразийства (Н. С. Трубецкой, П. Н. Савицкий, П. П. Сувчинский) является абсолютизация роли православия и православной церкви в жизни Евразии и, наоборот, недооценка интегрирующей роли буддизма в культурном становлении Евразии. И наконец, повторим, что Рерихи существенно раздвинули границы евразийского пространства, с полным основанием включив в него Индию, на чем мы ниже подробнее остановимся.

В обсуждении данной темы следует также принять во внимание биографию, общекультурный контекст и общее направление деятельности семьи Рерихов. Примечательны прежде всего ее этнические корни. Так, родословная Н. К. Рериха восходит к европейскому северу; фамилия «Рерих», как известно, скандинавского происхождения и словно отражает северо-западный, варяжский исток формирования русской культуры и государственности. Е. И. Рерих является правнучкой М. И. Кутузова, тюркские корни которого уходят в тот период истории, когда в XV-XVII вв. на службу к русскому князю переходят знатные служилые татаро-монгольские фамилии. Здесь символически обнаруживается юго-восточный - кочевой - фактор становления России как великого евразийского государства. Одновременно семейство Рерихов - плоть от плоти русской славянской культуры. Сам Н. К. Рерих, как известно, внес большой вклад в открытие и сохранение археологических и архитектурных памятников Тверской, Новгородской и других областей русского северо-запада. Его живописные полотна славянского цикла - важнейший вклад в российское духовное самосознание, но при этом на его полотнах Россия предстает именно как евразийская многонациональная держава, раскинувшаяся от Балтийского моря до Тихого океана, где православные монастыри стоят на высоких горах, половецкие становища органически соседствует со славянскими идолами, а «Настасья Микулична» выглядит как типичная монголка. Во многом здесь лежат корни его интереса к Востоку и желание исследовать влияние последнего на русскую культуру в разные исторические эпохи. «Вы знаете, что великая равнина России и Сибири после доисторических эпох, - писал Н. К. Рерих, - являлась ареной для шествий всех переселяющихся народов. Изучая памятники этих переселений, вы понимаете величие этих истинно космических переселений... После общечеловеческого иероглифа каменного века мы в последующие эпохи встречаем в недрах русской земли наслоения самые неожиданные; сопоставление этих неожиданностей помогает нам разобраться в лике действительной русской жизни... Еще сейчас в Тверской и Московской губерниях мы видим орнамент из древних оленей. Изображения этих животных относит взгляд непосредственно к каменному веку. В то же время в тех местах вы встретите ясно выраженную монгольскую вышивку. Или найдете ясные формы готского украшения» (Рерих, Н. К., 1991: 47).

Аалее следует отметить ключевые идеи мировоззрения Рерихов, обладающие несомненной близостью к положениям евразийства. Во-первых, это базовый принцип примата культуры над экономикой, духовных ценностей над материальными. «Царство всеобщего достатка, даже богатства, - справедливо писал Н. Н. Алексеев, может быть по существу своему просто большой свинарней» (Алексеев, 1998: 320). А Н. К. Рерих подчеркивал: «Что может заменить вопрос культуры?.. Во всей истории человечества ни продовольствие, ни промышленность не строили истинной культуры. И надлежит особенно бережно обойтись со всем, что еще может повысить уровень Ауха» (Рерих, Н. К., 1991: 39-40). 
Во-вторых, в идейном наследии семьи мы встречаем предупреждения против личного и группового эгоизма и конкуренции, логическим итогом которых всегда становятся вражда и война. В противовес этому Рерихи, наследуя традиции передовой отечественной общественно-политической мысли, выдвигают идеал кооперации, объединения усилий людей, социальных групп и народов Земли для совместного решения сложных проблем, которые приняли сегодня характер глобальных. В-третьих, как никогда актуально звучит призыв Рерихов к сохранению природы, к максимально разумному и рачительному использованию ее потенциала. Здесь они перекликаются с тезисом евразийцев о необходимости развести экономику и хозяйство: подлинный хозяин, по мнению П. Н. Савицкого, заботится не столько о получении прибыли, сколько о самом человеке - живом субъекте хозяйствования, а также о социальных и природных условиях его бытия (Савицкий, 1997: 218-219). В-четвертых, при развитии международного сотрудничества исключительно важна опора на общее культурно-историческое наследие народов, на уже сбывшиеся в истории образцы культурного синтеза и высокие образцы созидательного труда. Ю. Н. Рерих в работе «Культурное единство Азии» писал: «В поисках единства нам не следует забывать уроки прошлого, но, напротив, следует тщательно оберегать остатки былого единства и везде, где возможно, разжигать заново священный огонь культурного единения, культурного обмена, который когда-то принес человечеству благие плоды и которого так недостает нашему современному миру» (Рерих, 1999: 27).

Все сказанное, на наш взгляд, дает основание рассматривать наследие Рерихов как относительно самостоятельную вариацию евразийской идеи, преодолевающую многие недостатки классического евразийства и обладающую серьезным эвристическим и прогностическим потенциалом в нынешней исторической ситуации.

\section{ИНАИЯ КАК ЕВРАЗИЙСКАЯ СТРАНА \\ В ИССАЕАОВАНИЯХ РЕРИХОВ}

Вначале следует отметить, что Рерихи, конечно, не говорили об Индии как о евразийской стране в тех же терминах и в том же смысле, какой придавали этому понятию сами основоположники евразийства. Тем не менее в той или иной форме эта тема развивается во многих их работах, где Индия, по сути, рассматривается как неотъемлемая, хотя и «окраинная» часть единого культурно-географического мира.

Рерихи, образно говоря, продлили на юг важнейшую меридиональную, или «вертикальную», ось «континента “Евразия”», связав Сибирь и Индию (более узко Алтай и Гималаи, на чем мы ниже еще остановимся). Эта ось, по мнению Рерихов, обеспечивала историческое и культурное единство Евразии в широком смысле слова. «Проведите линию от южнорусских степей и от Северного Кавказа через степные области на Семипалатинск, Алтай, Монголию и оттуда поверните ее к югу, чтобы не ошибиться в главной артерии движения народов» (Рерих, 1992: 191). Здесь они преодолели ограниченность взгляда евразийцев, которыми не была по-настоящему учтена Индия и ее органическая связь с Северной (или Внутренней) Евразией, т. е. евразийским этнокультурным пространством в узком смысле, на чем так настаивал в свое время А. С. Хомяков. Как верно отмечает А. Ю. Сурина, Рерихи добавляют к «классическому» евразийскому пространству «соседние переходные и периферические, этнически и культурно родственные области, к которым относятся Западный Туркестан, Южный и Восточный Тибет, область верховий Желтой реки, западные окраины Маньчжурии, пространства Юга России вплоть до Северного Причер- 
номорья, Южной Сибири, Кавказа, Ирана, Афганистана, северо-запада Индии» (Сурина, 2010: 7).

Аанный подход у Рерихов не был умозрительной гипотезой. За ним стояла, во-первых, глубокая теоретическая подготовка: каждый из членов семьи был специалистом во многих областях науки и культуры. Н. К. Рерих и С. Н. Рерих - не только художники, имеющие мировую известность: Николай Константинович был археологом и историком, Святослав Николаевич - ботаником, геологом и орнитологом. Е. И. Рерих была глубоким знатоком восточной философии, и ее наследие заслуживает отдельного исследования. Ю. Н. Рерих закончил Гарвардский университет по отделению индийской филологии, был крупнейшим востоковедом, буддологом, исследователем Тибета; знал более тридцати европейских и азиатских языков и диалектов. Во-вторых, как известно, большая часть жизни семьи была связана с Индией. Труды и творчество не только Н. К. Рериха, но и С. Н. Рериха стали неотъемлемыми частями индийской культуры; их имение в г. Бангалоре - значимый культурный центр Индии и один из устоев индийско-русских культурных связей. Семья Рерихов приехала в Индию и навсегда осталась в ней жить, предварительно проехав и поработав как в Европе (Скандинавия, Англия, Франция), так и в США. В-третьих, огромный эмпирический материал был собран ими во время беспримерной по длительности и масштабу Трансгималайской экспедиции (1923-1928), куда они отправились, обогатившись знанием мировых культурных процессов и активно поучаствовав в них. Они были первыми русскими путешественниками, которым удалось напрямую пройти из Индии через Китай в Россию по одному из главных меридиональных евразийских караванных путей (через Каракорум и Синьцзян); посетить Москву и Алтай, а затем, уже по монгольско-тибетскому древнему пути, вновь вернуться в Индию. Фактически Рерихи прошли основными древними путями движения евразийских народов. Более того, этой экспедицией было положено начало активному научному сотрудничеству русских и индийских ученых в рамках института «Урусвати», который начал свою работу в гималайской долине Кулу в 1929 г. В ходе экспедиции были собраны уникальные коллекции, которые легли в основу работы института, и при нем был открыт целый ряд отделов (археологический, отдел естественных наук, медицинский), а также научная библиотека. С институтом «Урусвати» тесно сотрудничали ведущие ученые Индии и многих стран. В Индии это прежде всего Ч. В. Раман, Аж. Чандра Бош, Р. Тагор, А. Тагор, А. Кумар Халдар, С. Кумар Чаттерджи, Р. Чаттерджи, С. Радхакришнан, Т. Синг, К. П. П. Тампи, Р. М. Равал и другие. К числу западных ученых и партнеров относятся А. Эйнштейн, Р. Милликан, $\Lambda$. де Бройль, президент Американского археологического института Р. Магоффин и ряд других. В России с С. Н. Рерихом вел постоянную научную переписку академик Н. И. Вавилов. Как отмечает А. В. Баранов, весьма показательны также «интенсивные научные контакты Ю. Н. Рериха и крупнейшего европейского тибетолога, буддолога, знатока философии и искусства Тибета, создателя Института Среднего и Аальнего Востока (Is MEO) профессора Аж. Туччи» (Баранов, 2014: 384).

К сожалению, работа института продолжалась недолго, что было связано с разразившимся финансовым кризисом, затем со Второй мировой войной. Тем не менее за короткий период существования института было сделано очень многое; до сих пор изучена лишь часть его архивов.

Осмысление результатов экспедиции дало серьезные подтверждения тезису Рерихов о культурно-историческом единстве существенно более широкого евразийского 
пространства, чем предполагали основоположники евразийства. Выделим несколько основных моментов.

Прежде всего, это единство обусловливается, по мнению Рерихов, многочисленными и разноплановыми свидетельствами постоянных кросс-культурных связей между народами, населяющими данное пространство. Эти связи и взаимовлияния были результатом как наличия большого числа кочевых культур, как бы «сшивающих» восток и запад, север и юг Евразии, так и волн крупных миграций. В качестве фактических подтверждений следует напомнить, во-первых, открытие широчайшей распространенности от Тибета до Причерноморья скифско-сарматского звериного стиля. Вовторых, в ходе Трансгималайской экспедиции Рерихами был обнаружен целый ряд отдельных артефактов, также говорящих в пользу их гипотезы. Так, Н. К. Рерих пишет: «...На полпути от Кашмира на скалах начинают попадаться древние изображения. ...Одни более новые, более сухие по технике. В них можно рассмотреть намеки на буддийские предметы, стилизованные субурганы и так называемые счастливые знаки буддизма. Но рядом с ними иногда на тех же самых скалах вы видите сочную технику, относящую вас к неолиту... Характер этих рисунков потому заслуживает особого внимания, что те же древние изображения мы видели на скалах около оазиса Санджу в Сензиане, в Сибири, в Трансгималаях...» (Рерих, 1992: 171). Приведем еще одну показательную цитату: «Подробности одежды и вооружения тибетцев тоже дают поводы для значительных сопоставлений... Посмотрим фибулы, наплечные пряжки, и сравним их с такими же из аланских и готских погребений южной России и Европы. Вот передо мною фибула с изображением двуглавого орла - ведь та же стилизация была найдена на Кубани. Вот другая тибетская пряжка старинной работы из Аерге.

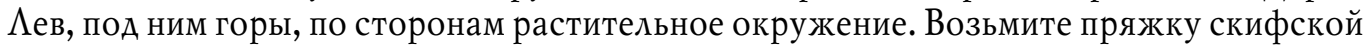
работы из находок Козлова, совпадающую даже по величине, и вы будете изумлены тем же характером изображения. Кроме менгиров и кромлехов в области ШендзаАзонга, тоже в Трансгималаях, нам удалось найти древние могилы, напомнившие алтайские погребения и могилы южных степей... В той местности Трансгималаев, называемой Аоринг... мы встретили совершенно необычайный для Тибета женский головной убор. Убор представлял собою ярко выраженный славянский кокошник, обычно красного цвета, украшенный бирюзою, серебряными монетами или унизанный бусами. Ни к северу, ни к югу подобный убор уже не был встречен. Очевидно, в этом месте находились остатки какого-то бывшего особого племени. Язык их ничем не отличается от прочих северных испорченных наречий» (Рерих Н. К., 1992: 206-207). Ю. Н. Рерих в очерке «Проблемы тибетской археологии» отмечает: «...Некоторые из них (наскальных рисунков. - A. И., И. Ф.) могут принадлежать к тому же времени, что и аналогичные рисунки, найденные в Южной Сибири, Монголии и Русском Туркестане» (Рерих, 2002b: 55). Отметим, что в связи с этими находками для Ю. Н. Рериха важным аспектом исследований стал поиск прародины индоевропейских племен, которую он, после обзора различных известных гипотез, связал с территорией от Карпат до Тянь-Шаня (Рерих, 2004: 94-95).

Аругим их важнейшим результатом и одновременно доводом в пользу евразийского характера Индии стало доказательство объединительной, культурно-духовной, а также миротворческой миссии буддизма в Центральной и Средней Азии в первой половине первого тысячелетия нашей эры. Именно буддизму многие народы были обязаны своим культурным и научным взлетом. «В течение первого тысячелетия нашей әры буддизм создал культурное единство, которое дало возможность идеям свобод- 
но расцвести и вызвало замечательный рост искусства и литературы, определивший уникальную позицию Индии в истории Азиатской культуры» (Рерих, 2002а: 11), — писал Ю. Н. Рерих, уточняя в другой работе, что «...распространение буддизма по ту сторону Гималаев... принесло послание Будды в Монголию и позднее, в XVII веке, в Сибирь» (Рерих, 2002с: 16).

И наконец, следует отметить мировоззренческую близость Индии - при всей частной разнице традиций отдельных населяющих ее этнических образований - к общему евразийскому «духу». Эта близость особенно отчетливо прорисовывается в сравнении с западным менталитетом. Еще Н. Я. Аанилевский писал: «Одна из таких черт, общих всем народам романо-германского типа, есть насильственность (Gewaltsamkeit). Насильственность, в свою очередь, есть не что иное, как чрезмерно развитое чувство личности, индивидуальности, по которому человек, им обладающий, ставит свой образ мыслей, свой интерес так высоко, что всякий иной образ мыслей, всякий иной интерес необходимо должен ему уступить, волею или неволею, как неравноправный ему... Такой склад ума, чувства и воли ведет в политике и общественной жизни... к крайнему политическому дроблению; в религии - к нетерпимости или к отвержению всякого авторитета (Аанилевский, 1991: 179-180). Н. С. Трубецкой, характеризуя европейскую культуру, также говорил об «эгоцентризме, проникающем всю их пресловутую “цивилизацию”» (Трубецкой, 1999: 85). В общеевразийском же менталитете до сих пор, даже несмотря на все цивилизационные сдвиги, доминируют коллективизм и соборность, примат непосредственных, межчеловеческих связей над опосредованными. Это в полной мере относится и к Индии, говоря о которой $\Lambda$. С. Васильев подчеркивает: «...для антично-капиталистической Европы была всегда характерна... иерархия связей: на первом плане рыночные, опосредованные частной собственностью, на втором - все остальные. Совершенно иная иерархия связей на традиционном Востоке... Высшее место занимают официальные, государственные, второе - корпоративные патронажно-клиентные, тесно переплетенные с официальными, а третье рыночные, тоже, к слову, далеко не свободные, как на Западе, но, напротив, опутанные связями двух других типов» (Васильев, 2001: 415).

Помимо этого, в качестве существенно общей черты следует назвать отмечаемый всеми исследователями глубинный религиозный (в широком смысле слова) базис менталитета евразийских народов и, разумеется, Индии. Религиозная основа мировоззрения устойчиво сохраняется, несмотря на столетия утверждаемого атеизма; при этом в евразийских странах она сегодня носит принципиально иной характер, чем в Европе и США с их во многом секуляризованным, прагматическим и «адаптированным» христианством. Мы не будем на этом останавливаться, так как данная тема, вопервых, достаточно хорошо исследована, и, во-вторых, ее обсуждение выходит за рамки статьи.

\section{ААТАЙ КАК ЦЕНТР ЕВРАЗИИ}

Особое значение в многовекторном объединении Евразии Рерихи придавали Алтаю как «Сердцу Азии», ее наиболее репрезентативному биосферному и этнокультурному региону. Известно, что институт «Урусвати» должен был быть первоначально развернут именно на Алтае. Это вполне объяснимо, если учесть, что Алтай - это вся Евразия в миниатюре с точки зрения представленности на ограниченной территории всех ее ландшафтно-географических зон, этносов и религий. Алтай - место схождения границ четырех крупнейших государств (России, Китая, Казахстана 
и Монголии); территория, по которой прошли десятки племен с Востока на Запад и с Запада на Восток.

И, видимо, не случайно сегодня все отчетливее выделяется направление исследований, связанное с выявлением биосферно-хозяйственных и историко-культурных параллелей и связей между Алтаем и Гималайским регионом Индии, также начатое еще семьей Рерихов и получившее отражение в известной книге «Алтай - Гималаи». Иными словами, можно сказать, что общность Индии и «классических» евразийских стран ярче всего демонстрируется в процессе сравнительного анализа этих двух горных регионов. На их общность Рерихи указывали неоднократно, отмечая, в частности, сходство менгиров, могильников и наскальных рисунков Алтая и Гималаев, особенно относящихся к скифо-сарматскому периоду (Рерих, 1992: 27-28). Сегодня, благодаря исследованиям немецкого ученого К. Йеттмара, можно говорить и о более ранних параллелях в петроглифах Алтая, Гималаев и Гиндукуша, восходящих к периоду ранней бронзы (III-II тыс. до н. э.) (см.: Кубарев, 2002: 40-41). О наличии непосредственных торговых и культурных связей между Алтаем и Гималаями свидетельствуют находки индийских бронзовых зеркал и рубашки из дикого гималайского шелкопряда в скифских могилах на Алтае (см.: Васильков, 2002). С достаточной уверенностью можно говорить и о существовании древнего кочевого и торгового пути между Западными Гималаями и Алтаем, шедшего из Кашмира через Трансгималаи и Каракорум в Восточный Туркестан, а оттуда через перевалы Канас и Ааян-Нур на русский и монгольский Алтай. Есть еще одна важная черта функционального сходства Алтая и Гималаев: они обеспечивают не только выживание народов и сохранение их культурного наследия, но активный этнокультурный диалог между ними. Именно в горных регионах мы видим, с одной стороны, наибольшее этнокультурное и религиозное разнообразие, а с другой - длительные и продуктивные кросс-культурные контакты, когда народы перенимают друг у друга многие религиозные представления, хозяйственные и бытовые навыки, не говоря уж о языковых заимствованиях. Например, в индийских Гималаях знаменитая долина Кулу называется «долиной тысячи богов», но при этом есть единые религиозные объекты почитания и праздники, которые отмечают все ее этнические группы: таково почитание реки Биас и праздник богини Трипурасундари (Верма, С., Верма Й., 2012). Аналогичная ситуация и на Алтае, где, например, река Катунь и гора Белуха почитались священными и русскими, и алтайцами. Есть крайне интересные лингвистические и религиозные параллели между культурой Алтая и Гималаев; например, священная трехглавая вершина в штате Ажамму носит название Трикута и является обителью Вайшну Аеви - Великой Богини Матери (Шапошникова, 1999: 160). Но в тюркских языках корень «кут» носит сакральный характер, обозначая одновременно и бессмертную часть человеческой души, и материнскую небесную субстанцию (душу) Космоса, куда индивидуальная душа человека на время возвращается после смерти физического тела. Та же Белуха в мифологии алтайских народов рассматривается как обитель богини-прародительницы Умай. Показательно, что в тексте «Махабхараты» найдены прямые упоминания об Алтае, в том числе и о горе Белухе, причем с тем же названием «Белая гора» (Шветапарвата, Шветагири) и почти точным указанием расстояния между ней и Гималаями (Останин, 2012: 36-38).

\section{ЗАКАЮЧЕНИЕ}

На основании всего сказанного можно резюмировать, что в работах Рерихов были заложены серьезные основания для признания евразийского статуса Индии и в целом 
Аля расширения границ евразийского пространства. Сегодня эти идея начинают получать практическое измерение. Как уже сказано, развиваются активные научные связи между Алтаем и Гималайским регионом в Индии. В частности, на базе университета г. Шимлы и общества «Калп» из гималайского штата Химачал-Прадеш, а также двух вузов из г. Барнаула - Алтайского государственного технического и Алтайского государственного аграрного университетов - начала действовать совместная научная программа «Алтайско-Гималайская инициатива». Уже выпущены совместные коллективные научные труды (см., напр.: Алтай - Гималаи ... , 2012, 2015) и проведены достаточно представительные научные форумы. Общность экологических, культурных и хозяйственных проблем двух великих горных регионов Земли, а также понимание их фундаментального значения для сохранения природного и культурного наследия народов Евразии служат основанием для разворачивания продуктивного многостороннего сотрудничества стран, входящих в «континент “Евразия”».

\section{СПИСОК АИТЕРАТУРЫ}

Алексеев, Н. Н. (1998) Русский народ и государство. М. : Аграф. 635 с.

Алтай - Гималаи: два устоя Евразии (2012) / под ред. С. П. Бансал. Барнаул : Изд-во АГАУ. 325 c.

Алтай - Гималаи: традиционные знания и инновации в развитии горных и предгорных регионов Евразии : матер. 1-го российско-индийско-монгольского семинара 19-20 июня 2015 г. Барнаул : Изд-во Фонда «Алтай-21 век», 2015. 232 с.

Баранов, А. В. (2014) К проблеме культурного единства Азии: некоторые аспекты наследия Ю. Н. Рериха // Труды Санкт-Петербургского гос. ун-та культуры и искусств. Т. 204. C. 380-397.

Васильев, А. С. (2001) История Востока : в 2 т. М. : Высшая школа. Т. 2.512 с.

Васильков, Я. В. (2002) Аревние индийские зеркала из скифо-сарматских курганов Алтая и Южного Приуралья // Степи Евразии в древности и средневековье : матер. Междунар. науч.практ. конф., посвящ. 100-летию со дня рождения М. П. Грязнова. СПб. : Гос. Эрмитаж. Кн. 2. 310 c. C. $28-33$.

Верма, С., Верма, Й. С. (2012) Химачал-Прадеш как обитель духовности // Алтай - Гималаи: два устоя Евразии / под ред. С. П. Бансал и др. Барнаул : Изд-во АГАУ. 325 с. С. 25-34.

Аанилевский, Н. Я. (1991) Россия и Европа. М. : Книга. 576 с.

Зелинский, А. Н. (1992) Рыцарь культуры [к 90-летию со дня рождения Ю. Н. Рериха]// Рерих Ю. Н. Звериный стиль у кочевников Северного Тибета. М. : Международный центр Рерихов. 40 с. С. $3-20$.

Зелинский, А. Н. (2003) То, что противостоит потоку текущего времени // 100 лет со дня рождения Ю. Н. Рериха : матер. Междунар. науч.-обществ. конф. 7-9 октября 2002 г. / под ред. Т. О. Книжник. М. : Международный центр Рерихов ; Мастер-Банк. 373 с. С. 55-60.

Иванов, А. В. (2003) Творческое наследие Рерихов и мировоззрение евразийцев // 100 лет со дня рождения Ю. Н. Рериха : матер. Междунар. науч.-обществ. конф. 7-9 октября 2002 г. / под ред. Т. О. Книжник. М. : Международный центр Рерихов ; Мастер-Банк. 373 с. С. 193-201.

Иванов, А. В., Попков, Ю. В., Тюгашев, Е. А., Шишин, М. Ю. (2007) Евразийство: ключевые идеи, ценности, политические приоритеты. Барнаул : Изд-во АГАУ. 243 с.

Иванов, А. В., Фотиева, И. В., Шишин, М. Ю. (2001) Ауховно-экологическая цивилизация: устои и перспективы. Барнаул : Изд-во Алтайск. гос. ун-та. 240 с.

Ключников, С. Ю. Философское наследие Рерихов и евразийство. [Электронный ресурс]// Электронная библиотека Международного центра Рерихов. URL: http://lib.icr.su/node/785 (дата обращения: 22.12.2015).

Кубарев, В. А. (2002) Алтай - древняя сокровищница Азии // Алтайский вестник. №2. C. 39-45. 
Останин, В. В. (2012) Гора Белуха в Махабхарате // Алтай - Гималаи: два устоя Евразии / под ред. С. П. Бансал и др. Барнаул : Изд-во АГАУ. 325 с. С. 34-48.

Рерих, Н. К. (1991) Пути благословения. Минск : Изд-во «Университетское». 103 с.

Рерих, Н. К. (1992) Сердце Азии // Рерих, Н. К. Цветы Мории. Пути благословения. Сердце Азии. Рига : Виеда. 261 с. С. 155-258.

Рерих, Ю. Н. (1992) Звериный стиль у кочевников Северного Тибета. М. : Международный центр Рерихов. 40 с.

Рерих, Ю. Н. (2002а) Буддизм и культурное единство Азии // Рерих, Ю. Н. Будаизм и культурное единство Азии : сб. ст. : пер. с англ. М. : Международный центр Рерихов ; Мастер-Банк. 127 c. C. $10-13$.

Рерих, Ю. Н. (2002b) Проблемы тибетской археологии // Рерих, Ю. Н. Буддизм и культурное единство Азии : сб. ст. : пер. с англ. М. : Международный центр Рерихов ; Мастер-Банк. 127 c. C. $50-63$.

Рерих, Ю. Н. (2002c) Тибетский буддизм [вариант первый] // Рерих, Ю. Н. Буддизм и культурное единство Азии : сб. ст. : пер. с англ. М. : Международный центр Рерихов ; Мастер-Банк. 127 c. C. $13-16$.

Рерих, Ю. Н. (2004) История Средней Азии : в 3 т. М. : Международный центр Рерихов. T. 1.463 c.

Рерих, Ю. Н. (1999) Тибет и Центральная Азия : лекции, статьи, переводы. Самара : Агни. 359 c.

Савицкий, П. Н. (1997) Хозяин и хозяйство // Савицкий, П. Н. Континент Евразия. М. : Аграф. 461 с. С. $217-253$.

Сурина, А. Ю. (2010) Единство культурного пространства древней Евразии в исследованиях Юрия Николаевича Рериха // Этногенез и ранняя история народов Евразии : матер. Междунар. науч.-практ. конф. 5-6 апреля 2010 г. / под ред. С. Н. Волкова, Б. А. Аорошина и др. Пенза ; Прага : ООО «Научно-издательский центр “Социосфера”». Вып. 2. 167 с. С. 5-16.

Трубецкой, Н. С. (1999) Европа и человечество // Трубецкой, Н. С. Наследие Чингисхана. М. : Аграф. 554 с. С. 29-90.

Шапошникова, $\Lambda$. В. (1999) Великое путешествие : в 3 кн. М. : Международный центр Рерихов ; Мастер-Банк. Кн. 2. С. 391-400.

Аата поступления: 12.09.2016 2.

THE PLACE OF INDIA IN THE EURASIANISM OF
A. V. IVANOV
(ALTAI STATE AGRARIAN UNIVERSITY),
I. V. FOTIEVA
(ALTAI STATE UNIVERSITY)

A number of recent studies both in Russia and abroad have confirmed the rise of interest in the doctrine of Eurasianism. Among them, of special importance is the discussion on which countries, in addition to those marked so by the founders of the movement, can be described as Eurasian. This discussion has proved promising both in terms of its theoretical significance and due to the need to understand the growing geopolitical role of the Eurasian space in the unstable world of today.

In this paper, we examine the view that in the works of the Roerich family (in particular those written on the basis of the materials collected during their Trans-Himalayan expedition), India is given the status of a Eurasian country. We prove that the heritage of the Roerichs can be seen as a relatively independent version of the Eurasian idea, the one which avoided many of the shortcomings of classical Eurasianism and still possesses a great heuristic and prognostic potential.

The Roerichs corrected the position of founding fathers of Eurasianism, who by oversight did not take India into account - India, with its organic unity with the North (Inner) Eurasia, i.e., with Eurasian ethno-cultural space in the narrow sense. The Roerichs believed this unity can be proved by 
numerous cases of cross-cultural relations between the peoples inhabiting this space. Thus, the Scythian and Sarmatian animal style was found to have been widespread on the vast expanses between the Tibet and the Black Sea (the Roerichs' expedition discovered numerous artifacts which confirmed this hypothesis). Another argument is found in large-scale cultural and spiritual presence of Buddhism in Central and Middle Asia during the first half of the first millennium CE. The proximity of Indian culture to the generic Eurasian «spirit» has been recently confirmed by a number of studies.

In conclusion, the authors note the special importance of the Altai as the most representative biospheric and ethno-cultural area of the multi-level Eurasian unity, closely linked to the Himalayan region in India.

Keywords: Eurasianism; Eurasia; India; the Roerich family; N. K. Roerich; Yu. N. Roerich; TransHimalayan expedition, Urusvati Institute; cross-cultural communication; Altai

\section{REFERENCES}

Alekseev, N. N. (1998) Russkii narod i gosudarstvo. Moscow, Agraf. 635 p. (In Russ.)

Altai - Gimalai: dva ustoia Evrazii (2012), ed. by S. P. Bansal et al. Barnaul, Izd-vo AGAU. 325 p. (In Russ.)

Altai - Gimalai: traditsionnye znaniia $i$ innovatsii $v$ razvitii gornykb $i$ predgornykb regionov Evrazii (2015) : mater. 1-go rossiisko-indiisko-mongol'skogo seminara 19-20 iiunia 2015 g. Barnaul, Izd-vo Fonda Altai-21 vek. 232 p. (In Russ.)

Baranov, A. V. (2014) K probleme kul'turnogo edinstva Azii: nekotorye aspekty naslediia Yu. N. Rerikha. Trudy Sankt-Peterburgskogo gos. un-ta kul' tury i iskusstv. Vol. 204. Pp. 380-397. (In Russ.)

Vasil'ev, L. S. (2001) Istoriia Vostoka : in 2 vols. Moscow, Vysshaia shkola. Vol. 2. 512 p. (In Russ.)

Vasil'kov, Ya. V. (2002) Drevnie indiiskie zerkala iz skifo-sarmatskikh kurganov Altaia i Yuzhnogo Priural'ia. In: Stepi Evrazii v drevnosti i srednevekov'e : mater. Mezhdunar. nauch.-prakt. konf., posviashch. 100-letiiu so dnia rozhdeniia M. P. Griaznova. St. Petersburg, Gos. Ermitazh. Bk. 2. 310 p. Pp. 28-33. (In Russ.)

Verma, S., Verma, I. S. (2012) Khimachal-Pradesh kak obitel' dukhovnosti. In: Altai - Gimalai: dva ustoia Evrazii, ed. by S. P. Bansal et al. Barnaul, Izd-vo AGAU. 325 p. Pp. 25-34. (In Russ.)

Danilevskii, N. Ya. (1991) Rossiia i Evropa. Moscow, Kniga. 576 p. (In Russ.)

Zelinskii, A. N. (1992) Rytsar' kul'tury [k 90-letiiu so dnia rozhdeniia Yu. N. Rerikha]. In: Roerich Yu. N. Zverinyi stil' u kochevnikov Severnogo Tibeta. Moscow, Mezhdunarodnyi tsentr Rerikhov. 40 p. Pp. 3-20. (In Russ.)

Zelinskii, A. N. (2003) To, chto protivostoit potoku tekushchego vremeni. In: 100 let so dnia rozbdeniia Yu. N. Rerikba: mater. Mezhdunar. nauch.-obshchestv. konf. 7-9 oktiabria 2002 g., ed. by T. O. Knizhnik. Moscow, Mezhdunarodnyi tsentr Rerikhov; Master-Bank. 373 p. Pp. 55-60. (In Russ.)

Ivanov, A. V. (2003) Tvorcheskoe nasledie Rerikhov i mirovozzrenie evraziitsev In: 100 let so dnia rozbdeniia Yu. N. Rerikba: mater. Mezhdunar. nauch.-obshchestv. konf. 7-9 oktiabria 2002 g., ed. by T. O. Knizhnik. Moscow, Mezhdunarodnyi tsentr Rerikhov; Master-Bank. 373 p. Pp. 193-201. (In Russ.)

Ivanov, A. V., Popkov, Yu. V., Tiugashev, E. A., Shishin, M. Yu. (2007) Evraziistvo: kliuchevye idei, tsennosti, politicheskie prioritety. Barnaul, Izd-vo AGAU. 243 p. (In Russ.)

Ivanov, A. V., Fotieva, I. V., Shishin, M. Yu. (2001) Dukbovno-ekologicheskaia tsivilizatsiia: ustoi i perspektivy. Barnaul: Izd-vo Altaisk. gos. un-ta. 240 p. (In Russ.)

Kliuchnikov, S. Yu. Filosofskoe nasledie Rerikhov i evraziistvo [online] Elektronnaia biblioteka Mezhdunarodnogo tsentra Rerikhov. Available at: http://lib.icr.su/node/785 (access date: 22.12.2015). (In Russ.)

Kubarev, V. D. (2002) Altai - drevniaia sokrovishchnitsa Azii. Altaiskii vestnik, no. 2, pp. 39-45. (In Russ.)

Ostanin, V. V. (2012) Gora Belukha v Makhabkharate. In: Altai - Gimalai: dva ustoia Evrazii, ed. by S. P. Bansal et al. Barnaul, Izd-vo AGAU. 325 p. Pp. 34-48. (In Russ.) 
Roerich, N. K. (1991) Puti blagosloveniia. Minsk, Izd-vo Universitetskoe. 103 p. (In Russ.)

Roerich, N. K. (1992) Serdtse Azii // Roerich, N. K. Tsvety Morii. Puti blagosloveniia. Serdtse Azii. Riga, Vieda. 261 p. Pp. 155-258. (In Russ.)

Roerich, Yu. N. (1992) Zverinyi stil' u kochevnikov Severnogo Tibeta. Moscow, Mezhdunarodnyi tsentr Rerikhov. 40 p. (In Russ.)

Roerich, Yu. N. (2002a) Buddizm i kul'turnoe edinstvo Azii. In: Roerich, Yu. N. Buddizm i kul' turnoe edinstvo Azii : sbornik statei. Moscow, Mezhdunarodnyi tsentr Rerikhov; Master-Bank. 127 p. Pp. 10-13. (In Russ.)

Roerich, Yu. N. (2002b) Problemy tibetskoi arkheologii. In: Rerikh, Yu. N. Buddizm i kul'turnoe edinstvo Azii : sbornik statei. Moscow, Mezhdunarodnyi tsentr Rerikhov; Master-Bank. 127 p. Pp. 50-63. (In Russ.)

Roerich, Yu. N. (2002c) Tibetskii buddizm [variant pervyi] In: Rerikh, Yu. N. Buddizm i kul'turnoe edinstvo Azii : sbornik statei. Moscow, Mezhdunarodnyi tsentr Rerikhov ; Master-Bank. 127 p. Pp. 13-16. (In Russ.)

Roerich, Yu. N. (2004) Istoriia Srednei Azii : in 3 vols. Moscow, Mezhdunarodnyi tsentr Rerikhov. Vol. 1. 463, [3] p. (In Russ.)

Roerich, Yu. N. (1999) Tibet $i$ Tsentral'naia Aziia : lektsii, stat'i, perevody. Samara, Agni. 359 p. (In Russ.)

Savitskii, P. N. (1997) Khoziain i khoziaistvo. In: Savitskii, P. N. Kontinent Evraziia. Moscow, Agraf. 461 p. Pp. 217-253. (In Russ.)

Surina, A. Yu. (2010) Edinstvo kul'turnogo prostranstva drevnei Evrazii v issledovaniiakh Yuriia Nikolaevicha Rerikha. In: Etnogenez i ranniaia istoriia narodov Evrazii : mater. Mezhdunar. nauch.prakt. konf. 5-6 aprelia 2010 g., ed. by S. N. Volkov, B. A. Doroshin et al. Penza; Prague, OOO «Nauchno-izdatel'skii tsentr "Sotsiosfera"». Iss. 2. 167 p. Pp. 5-16. (In Russ.)

Trubetskoi, N. S. (1999) Evropa i chelovechestvo. In: Trubetskoi, N. S. Nasledie Chingiskbana. Moscow, Agraf. 554 p. Pp. 29-90. (In Russ.)

Shaposhnikova, L. V. (1999) Velikoe puteshestvie: in 3 bks. Moscow, Mezhdunarodnyi tsentr Rerikhov; Master-Bank. Bk. 2. P. 391-400. (In Russ.)

Submission date: 12.09 .2016

Иванов Андрей Владимирович - доктор философских наук, профессор, заведующий кафедрой философии Алтайского государственного аграрного университета, г. Барнаул. Адрес: 656049, Россия, г. Барнаул, пр-т Красноармейский, А. 98. Тел.: +7 (3852) 628-046. Эл. адрес: ivanov_a_v_58@mail.ru

Фотиева Ирина Валерьевна - доктор философских наук, доцент, профессор кафедры теории и практики журналистики Алтайского государственного университета. Адрес: 656049, Россия, г. Барнаул, пр-т Аенина, д. 61. Тел.: +7 (385-2) 291-291. Эл. адрес: fotieva@bk.ru

Ivanov Andrey Vladimirovich, Doctor of Philosophy, Professor and Chair, Department of Philosophy, Altai State Agricultural University. Postal address: 98 Krasnoarmeiskii Prospekt, Barnaul, Russian Federation 656049. Tel.: +7 (3852) 628-046. E-mail: ivanov_a_v_58@mail.ru

Fotieva Irina Valerievna, Doctor of Philosophy, Professor, Department of the Theory and Practice of Journalism, Altai State University. Postal address: 61 Lenin St., Barnaul, Russian Federation 656049. Tel.: +7 (385-2) 291-291. E-mail: fotieva@bk.ru 